\title{
Well made places: resident satisfaction in New Urban communities
}

\author{
G. Sands ${ }^{1} \&$ L. A. Reese ${ }^{2}$ \\ ${ }^{1}$ Wayne State University, USA \\ ${ }^{2}$ Michigan State University, USA
}

\begin{abstract}
The principles of New Urbanism advocate a form of urban development that incorporates higher densities, mixed uses and a pedestrian (rather than an automobile) oriented public realm. This paradigm is quite distinct from the typical suburban pattern of development that prevails in most of North America. Residents in two New Urban communities were surveyed on their relative levels of satisfaction with those characteristics of their neighbourhoods that set these places apart from the surrounding areas. This research suggests that there is considerable support for most elements of New Urbanism; satisfaction levels were not, however, significantly higher among residents of the development that was more consistent with New Urban principles.
\end{abstract}

Keywords: New Urbanism, residential density, housing preferences, suburban development.

\section{Introduction}

Since the middle of the last century, the predominant form of urban development in North America has been suburban, characterized by low densities, large-scale homogeneous development and automobile dependency. Despite criticisms from a range of perspectives, [1-3], this model of development remains the preferred form, shaping suburban communities in both Canada and the United States. While some new development models, such as Master Planned Communities [4] and Planned Unit Developments [5], have been offered as alternatives, they have had limited application and the results have often differed little from the prevailing suburban development paradigm. 
A more radical departure from the suburban standard has emerged over the last three decades, one that combines high standards of urban design with principles of social engineering. Led by architects Andres Duany [6] and Peter Calthorpe [7], and popularised by writers like Philip Langdon [8] and James Howard Kunstler [9], New Urbanism has been promoted as a model for development that not only looks better but also works better than the typical post-War suburb [10]. New Urbanism argues that the physical form of communities following their precepts facilitates a higher level of social interaction that contributes to a sense of community that is missing from the suburbs where a majority of North Americans live [11]. New Urbanism provides a template for building better suburbs as well as for renewing central cities [12].

The New Urban model draws on a number of diverse themes. Its emphasis on the public realm and the creation of a sense of place [13] addresses the widespread alienation and anomie prevailing in suburbs [14, 15]. New Urbanism emphasizes the preservation of important elements of the natural and built environment, heritage properties in particular [16]. The fine-grained mixture of land uses that facilitates non-motorized transportation and public transit supports both health and environmental values [7, 17].

Opinion surveys and market research suggest that a substantial proportion of the North American population would actually prefer to live in a community with the characteristics of a New Urban Development [11]. Despite the expressed preferences for (or at least interest in) the ideals of New Urbanism, the suburban model continues to prevail. In part this is the result of municipal development regulations that make it difficult if not impossible to develop communities that follow the principles of New Urbanism. This paper will examine how residents of two New Urban developments in Canada react to the reality of living in a community that incorporates the ideals of this new paradigm.

\section{New Urban developments}

New Urban developments can be found across North America; there are currently more than 300 such developments either planned or under construction [18]. As was the case with earlier attempts to introduce new development paradigms, such as the Garden City movement, most examples of New Urbanism are 'hybrids' that incorporate some of the tenets, but have been adopted to appease local markets and development regulations. While the majority of these are in suburban locations, the New Urban model has been used to guide the redevelopment of inner city neighbourhoods as well [12].

\subsection{Bois Franc. St-Laurent Quebec}

Bois Franc is a large infill development in Ville St-Laurent, well within the perimeter of the Montreal Urban Community. The site is a former airfield that is being developed by the real estate arm of the Bombardier Company, a large industrial firm. Plans for the site include light industrial and warehouse uses, a 
Commercial area, an 18-hole championship golf course and a mix of residential uses [6]. Open space, including the golf course and water features will occupy about one-sixth of the site. Most of the residential development consists of multifamily housing, including owner-occupied garden apartments and row houses, as well as rental apartments. The number of single-family homes is limited. About $30 \%$ of the 8,000 housing units planned for Bois Franc have been completed since the project began in 1994 [20].

This development is distinct from the surrounding community of St-Laurent in several ways (Table 1). It has a much higher rate of owner occupancy than the surrounding area and home values and rental rates are about $25 \%$ above the community average. Census data indicate that Bois Franc households are more likely to have children at home, be younger and have higher incomes. There are relatively fewer foreign-born residents and visible minorities in Bois Franc. The median household income for Bois Franc households is about double the StLaurent figure.

Table 1: Community characteristics.

\begin{tabular}{|l|c|c|c|c|}
\hline & Bois Franc & St-Laurent & Cornell & Markham \\
\hline Population & 3,578 & 77,390 & 5,779 & 208,615 \\
\hline Ave. Household Size & 2.48 & 2.52 & 3.24 & 3.44 \\
\hline HH with children & $46 \%$ & $38 \%$ & $66 \%$ & $59 \%$ \\
\hline Population $65+$ & $5 \%$ & $38 \%$ & $7 \%$ & $10 \%$ \\
\hline Median Household Income & $\$ 43,379$ & $\$ 39,412$ & $\$ 76,399$ & $\$ 77,163$ \\
\hline University Graduate & $55 \%$ & $34 \%$ & $24 \%$ & $35 \%$ \\
\hline
\end{tabular}

Source: Statistics Canada, 2001.

Designed by Daniel Arbour, Bois Franc departs form the principles of New Urbanism in several respects. The street system is a discontinuous grid and provides only limited connectivity within the development and to the surrounding community. Substantial residential development was in place before any of the commercial facilities were built. Public facilities, such as schools will not be part of the development. Public transportation in the form of buses is available at the site and a subway line ends about half a mile from the development.

The local housing market in the Montreal metropolitan area has experienced relatively slow growth in recent years. New housing starts within the Montreal Urban Community have been dominated by multifamily housing, either high-rise condominiums in the city centre or attached housing developments on infill parcels. Most of the new single-family development is occurring at locations far from the core.

\subsection{Cornell, Markham, Ontario}

The Cornell development is located in the Town of Markham, about 16 miles (27 kilometres) northeast of downtown Toronto. The 2,400 acre site will include 10,000 homes, employment for 16,000 persons, a dozen schools and other 
commercial facilities, as well as commercial facilities to serve local and regional needs and a business park. About half of the site will be reserved for green space [21].

The rapid growth of Markham during the 1990s (fully one-quarter of the housing stock in this community of 200,000 was built between 1996 and 2001) prompted the community to adopt development regulations that followed the New Urban principles of higher density, mixed uses, alternate modes of transit and high quality design standards [22]. The intent was to slow the pace of land development and reduce infrastructure costs by encouraging more compact developments, while still preserving a high quality of life for residents. Markham has seen the creation of a number of residential developments that follow New Urban criteria. Cornell is one of the largest of these and perhaps the most consciously New Urban.

The original design by Duany Plater-Zyberk has been modified somewhat to meet local standards but maintains a neighbourhood structure in which each neighbourhood offers a variety of land uses and housing types [23]. The developers have sought to ensure that neighbourhood commercial facilities, schools and recreational facilities have been built concurrently with the residential stock in each neighbourhood. The street pattern is orthogonal with a clear hierarchy, with wider roads bounding the neighbourhoods.

Overall, the profile of Cornell residents is similar to that of Markham in general. Cornell includes lower proportions of university graduates and visible minorities than the rest of Markham. Although average household size is lower in Cornell, community residents are somewhat more likely to include children. Median household income is slightly less than the community average. Home values and rents are slightly less than the community average and noticeably below those in other new developments.

\section{Resident survey}

\subsection{Methodology}

A mail survey was sent to a systematic sample of residents of these two New Urban communities in 2003 to assess their preferences and levels of satisfaction with their neighbourhood. The survey was prepared in both French and English and mailed to about 250 valid addresses. Recipients were asked to complete the survey and return it in a postage paid envelope. One reminder postcard was sent. The resulting response rate was about 30 percent overall. The number of responses from Bois Franc residents was slightly higher than from Cornell residents.

The surveys asked recipients to rate the relative importance of a number of housing and neighbourhood characteristics in their choice of a new home. The list included general considerations (home size and price) as well as distinctively New Urban attributes, such as density, pedestrian friendliness of the environment, a range of community facilities, and urban design features. 


\subsection{Respondent characteristics}

The characteristics of the survey respondents are summarized in Table 2. Both samples were quite comparable with respect to average household size and proportion of households with children. Respondents were equally likely to have a University or graduate degree and work in a professional occupation. Bois Franc respondents were relatively younger than those in Cornell, with only about one-third of the householders over the age of 45. All of the respondents were homeowners; both developments had only limited rental housing available at the time of the survey.

Table 2: $\quad$ Profile of respondents.

\begin{tabular}{|l|c|c|}
\hline & Bois Franc & Cornell \\
\hline Average Household Size & 3.13 & 3.14 \\
\hline Households with Children & $57 \%$ & $58 \%$ \\
\hline Head Age 45+ & $33 \%$ & $50 \%$ \\
\hline University Degree & $55 \%$ & $58 \%$ \\
\hline Professional Occupation & $85 \%$ & $84 \%$ \\
\hline Home Owner & $100 \%$ & $100 \%$ \\
\hline
\end{tabular}

Over 90 percent of respondents were the first occupants of their unit. The average length of time that they had occupied their home was just under four years. The average length of tenure in Bois Franc was slightly higher than in Cornell. Over $80 \%$ of the households in both samples reported that they had looked at other housing before deciding to purchase their current home. About half of the Bois Franc households shopped for homes in either other St-Laurent neighbourhoods or other municipalities. Three-quarters of the Cornell respondents had looked at homes in other Markham neighbourhoods, while just one-third had shopped in other municipalities.

Table 3: Average preference ratings.

\begin{tabular}{|l|c|c|c|}
\hline & Bois Franc & Cornell & Total \\
\hline Home cost & 4.33 & 4.61 & 4.46 \\
\hline Neighbourhood Appearance & 4.58 & 4.42 & 4.50 \\
\hline Housing Styles & 4.15 & 4.08 & 4.12 \\
\hline Size of Home & 4.20 & 3.97 & 4.09 \\
\hline Sidewalks & 4.03 & 4.14 & 4.08 \\
\hline Landscaping & 4.05 & 4.00 & 4.03 \\
\hline Neighbours & 3.60 & 4.47 & 4.01 \\
\hline Live in Neighbourhood & 3.63 & 4.22 & 3.91 \\
\hline
\end{tabular}

\subsection{Preferences}

The survey asked respondents to rank their satisfaction with 20 attributes of their new housing unit and their neighbourhoods on a scale of one to five. While 
Housing Cost was important in both samples (Table 3), many of the other highly ranked attributes related to the quality of the public realm. Among Cornell residents in particular, New Urban touchstones, such as Neighbours and Living in a Neighbourhood, were among the most important considerations.

An exploratory factor analysis was used to reduce the 20 variables to six factors, which together explained over $68 \%$ of the variance in housing preferences. Four of these (Diversity, Public Realm, Child Friendly and Accessibility) related to the attributes of the neighbourhood. The other two factors concerned the characteristics of the individual dwelling, with attributes of the dwelling unit being distinct from a factor that included the Front and Rear Yard measures.

Table 4: $\quad$ Preference factors.

\begin{tabular}{|l|c|c|}
\hline Factor & $\begin{array}{c}\text { Percentage of } \\
\text { variance }\end{array}$ & $\begin{array}{c}\text { Cumulative percentage of } \\
\text { variance }\end{array}$ \\
\hline Diversity & 16.409 & 16.409 \\
\hline Public Realm & 13.681 & 3.090 \\
\hline Child Friendly & 12.009 & 42.098 \\
\hline Accessibility & 10.488 & 52.586 \\
\hline House & 8.157 & 60.743 \\
\hline Yard & 7.700 & 68.442 \\
\hline
\end{tabular}

Table 5 presents the average preference rankings for each of the factors, on a scale of one (least important) to five (most important). Overall the individual dwelling was the most important consideration while the Yard was the least important. The quality of the Public Realm (Neighbourhood Appearance, Housing Styles and Variety, Landscaping and Traffic) received the next highest ranking, followed by a Child Friendly (Recreation, Schools, Playgrounds and Sidewalks). With the exception of the Diversity factor (Housing Type and Price variety, Living in a Neighbourhood, Neighbours, Friendly Neighbours), there is no significant difference between the average scores for the sub-samples. Diversity received preference higher ratings in Cornell than Bois Franc.

Table 5: $\quad$ Preference factor average scores.

\begin{tabular}{|l|c|c|c|}
\hline Factor & Bois Franc & Cornell & Total \\
\hline Diversity & 3.218 & 3.871 & 3.527 \\
\hline Public Realm & 3.781 & 3.946 & 3.859 \\
\hline Child Friendly & 3.700 & 3.694 & 3.697 \\
\hline Accessibility & 3.042 & 3.093 & 3.066 \\
\hline House & 4.263 & 4.292 & 4.276 \\
\hline Yard & 2.500 & 2.264 & 2.387 \\
\hline
\end{tabular}

In addition to ranking the importance of these housing and neighbourhood characteristics, respondents were asked to indicate their preferences for three 
specific neighbourhood attributes: whether the neighbourhood included a mix of single family and multifamily housing, whether it included a mix of housing and commercial uses, and whether it had a number of small community spaces throughout the neighbourhood rather than a single large one. The mixing of housing types and land uses and the provision of numerous local community spaces are important characteristics of New Urban development.

The majority of Bois Franc respondents indicated a preference for a neighbourhood without multifamily housing or commercial activities. The community where they did purchase their home, however, consists primarily of multifamily housing but at the time offered very little local shopping within the development. A majority of respondents preferred small neighbourhood community space to a large park.

Cornell residents on the other hand clearly preferred a community more representative of New Urban ideals. Between two-thirds and three-quarters of the Cornell surveys indicated a preference for mixed housing types and land uses within their neighbourhood. These results are significantly different than for the Bois Franc responses. Cornell residents were slightly less likely to favour neighbourhood parks than their Bois Franc counterparts, but the difference is not significant.

\subsection{Satisfaction measures}

The survey also asked respondents to provide ratings of their satisfaction with 15 aspects of their new home and neighbourhood. A factor analysis of the responses produced five factors, which together explained just over $73 \%$ of the variation in neighbourhood satisfaction. The Urban Design factor includes responses to questions about neighbourhood appearance, parks and open space, and density. Parking, vehicle traffic and public transportation loaded on the Traffic factor. The House factor includes the size of the dwelling and the adequacy of the yard space.

Table 6: $\quad$ Satisfaction factors.

\begin{tabular}{|l|c|c|c|}
\hline & Bois Franc & Cornell & Total \\
\hline Urban Design & 3.385 & 2.875 & 3.140 \\
\hline Traffic & 2.913 & 2.981 & 2.669 \\
\hline Accessibility & 2.888 & 2.444 & 2.678 \\
\hline Pedestrian Oriented & 2.975 & 2.611 & 2.803 \\
\hline House & 3.225 & 2.815 & 3.031 \\
\hline
\end{tabular}

Resident satisfaction is highest for the Urban Design factor, followed relatively closely by the House Factor. Unlike the preference factors described above, where there were generally no significant differences between the two samples, the reported satisfaction levels are significantly different for each of the factors. With the exception of the Traffic factor, Bois Franc respondents report a higher level of satisfaction with their present situation than Cornell residents. 
Most of this difference is attributable to parking problems that have been experienced by Bois Franc residents [24].

Respondents were also asked to provide a summary evaluation of both their new home and neighbourhood on a scale of one to ten, with ten being the most favourable rating. Most respondents appear to be quite satisfied with their houses. Fewer than $20 \%$ of all respondents gave their dwelling a rating lower than eight. Cornell residents were somewhat more likely to provide a rating of eight or more than Bois Franc respondents, but the difference is not significant.

Respondents were even more positive about their new neighbourhoods. Over $92 \%$ of the responses indicate a level of satisfaction of eight or more. The average neighbourhood rating in both locations was about 8.5.

Table 7: $\quad$ Regression results.

\begin{tabular}{|l|c|c|c|}
\hline & Standardized Beta & $\mathrm{t}$ & Sig. \\
\hline Constant & 3.883 & 3.206 & 0.000 \\
\hline Urban Design & 0.317 & 2.662 & 0.010 \\
\hline Traffic Satisfaction & -0.108 & -0.987 & 0.327 \\
\hline Accessibility & 0.150 & 1.472 & 0.146 \\
\hline Pedestrian Oriented & 0.287 & 2.494 & 0.015 \\
\hline Dwelling Satisfaction & 0.018 & 0.174 & 0.862 \\
\hline
\end{tabular}

The summary satisfaction rating was regressed against the calculated satisfaction factors to identify the elements making the largest contributions to the overall satisfaction level. The resulting regression equation has an $\mathrm{R}$ square value of 0.433 and is significant at the 0.000 level. The two variables that have a significance of 0.02 or less are the Urban Design and Pedestrian Oriented factors. When regression analyses were done for the Toronto and Montreal samples separately, the Bois France regression had only one significant variable, Urban Design factor at 0.006 , the Accessibility factor having a significance of 0.067. The Cornell regression, on the other hand, had the same significant factors as the combined sample. The R square for the Cornell sample was 0.473 and for the Bois Franc sample 0.612.

There was a high degree of correlation among the satisfaction factors. The Urban Design factor was significantly related to each of the other Satisfaction factors at the 0.01 level. The Pedestrian Oriented factor is also significantly related to each of the other factors, with a slightly less significant correlation with the Traffic factor.

There are, however, few significant correlations between the Satisfaction factors and the Preference factors. For example, the correlation between the Housing preference factor and the Housing satisfaction factor is low (-0.096) and not significant. The correlations between the Urban Design factor and the preference factors relating to diversity and the public realm are even less robust. This random association between the two sets of similar factors suggests that, even when respondents attached considerable importance to an attribute as a search criterion, they were not always satisfied with their housing choice. 
Table 8: $\quad$ Satisfaction factors correlation matrix.

\begin{tabular}{|l|c|c|c|c|c|}
\hline & $\begin{array}{c}\text { Urban } \\
\text { Design }\end{array}$ & Traffic & Accessibility & $\begin{array}{c}\text { Pedestrian } \\
\text { Oriented }\end{array}$ & House \\
\hline $\begin{array}{l}\text { Urban } \\
\text { Design }\end{array}$ & 1 & $0.525^{* *}$ & $0.338^{* *}$ & $0.483^{* *}$ & $0.413^{* *}$ \\
\hline Traffic & $0.525^{* *}$ & 1 & $0.385^{* *}$ & $0.286^{*}$ & 0.103 \\
\hline Accessibility & $0.338^{*}$ & $0.385^{* *}$ & 1 & $0.296^{* *}$ & 0.033 \\
\hline $\begin{array}{l}\text { Pedestrian } \\
\text { Oriented }\end{array}$ & $0.483^{* *}$ & $0.286^{*}$ & $0.296^{* *}$ & 1 & $0.485^{* *}$ \\
\hline House & $0.413^{* *}$ & $0.103^{* *}$ & 0.033 & $0.485^{* *}$ & 1 \\
\hline
\end{tabular}

*Significant at the 0.05 level.

**Significant at the 0.01 level.

\section{Conclusions}

Some obvious limitations to this research require that it be considered exploratory. Not only are the sample sizes relatively low, but respondents represent a subset of the general population that has actually moved to a new housing development that incorporates the principles of New Urban design. Thus, it is not surprising that respondents in both samples considered the New Urban elements to be important in their search for a new home. This research says nothing about the strength of preferences of households that did not elect to move to a New Urban community.

Nevertheless, the research suggests some interesting conclusions. There was considerable similarity in the preferences of respondents in the Quebec and Ontario samples, despite the fact that the two groups faced very different housing market situations. The St-Laurent area is essentially a fully developed (with the exception of the Bois Franc property) inner suburb that offers few choices of new housing. Markham, on the other hand, is a fast growing community on the urban periphery, where New Urban and suburban housing developments are being marketed. Indeed, the Town of Markham actively promotes the concepts of New Urbanism. It is remarkable that the samples nevertheless gave priority to the same sorts of neighbourhood attributes.

At present, Bois Franc is much more of a New Urban "hybrid" than Cornell. Bois Franc offers a high proportion of multifamily housing (often with limited orientation to the public realm), limited commercial facilities, a low proportion of green space (not all of which is public), and an almost total lack of public buildings in the community. Cornell is quite self-consciously New Urban and clear efforts have been made to ensure that New Urban criteria are maintained. Yet, there are few significant differences in the overall levels of satisfaction between the residents of the two communities. Bois Franc residents are more likely to report dissatisfaction with shopping and schools, both of which were lacking in the development at the time of the survey. But the Bois Franc residents of walk-up flats were as likely to be satisfied with their yard space as were the single-family home residents in Cornell. 
Residents of both Bois Franc and Cornell tended to express greater satisfaction with their neighbourhood than with their house. This uncommon result, combined with the similarities in ratings of individual elements noted above, suggests that not all of the New Urban elements are equally valuable or essential. Providing neighbourhood shops and cafés concurrently with the initial residential development, as in Cornell, may not have a substantial effect on satisfaction or marketability.

What was of highest importance in both communities is the quality of the public realm - the overall appearance of the neighbourhood, the residential density and the mix of development and open space. Pedestrian accessibility to was also important. Public transit and adult recreation facilities contributed little to neighbourhood satisfaction. It would appear that, at least for these respondents, something less than the comprehensively planned and managed New Urban development still provides an attractive alternative so long as it offers a well designed and attractive public realm.

\section{Acknowledgement}

The financial support of the Government of Quebec, Ministry of State for International Relations is gratefully acknowledged.

\section{References}

[1] Jacobs, J. Death and Life of Great American Cities. Vintage Books: New York, 1961.

[2] Downs, A. New Visions for Metropolitan America. The Brookings Institution: Washington DC, 1994.

[3] Cervero, R. Suburban Gridlock. Rutgers University Center of Urban Policy Research: New Brunswick NJ, 196.

[4] Campbell, C. C. New Towns: Another Way to Live. Reston Publishing Company: Reston VA: 1976.

[5] Moore, C. G. and C. Siskin. PUDS in Practice. ULI- The Urban Land Institute: Washington DC, 1985.

[6] Duany, A. E. Plater-Zyberk and J. Speck. Suburban Nation. North Point Press: New York, 2000

[7] Calthorpe, P. The Next American Metropolis. Princeton Architectural Press: New York, 1993.

[8] Langdon, P. A Better Place to Live. University of Massachusetts Press: Amherst MA, 1994.

[9] Kunstler, J. H. The Geography of Nowhere. Simon and Schuster: New York, 1993.

[10] Steuteville, R. and P. Langdon. New Urbanism. New Urban News: Ithaca, NY, 2003.

[11] Katz, P. The New Urbanism: Toward an Architecture of Community. Print Vision: Portland OR, 1994. 
[12] Duany, A. A New Theory of Urbanism. Scientific American. 283: 6. December 2000.

[13] Talen, E. Measuring the Public Realm. Journal of Architectural and Planning Research. 36(8): pp. 344-360.

[14] Putnam, R. D. Bowling Alone. Simon and Schuster: New York, 2000.

[15] Brindley, T. The social dimension of the urban village. Urban Design International. 8, pp.53-65.

[16] Congress for the New Urbanism. Charter of the new urbanism. www.cnu.org/aboutcnu/

[17] Frumkin, H., L. Frank and R. Jackson. Urban Sprawl and Public Health. Island Press: Washington, 2004.

[18] Steuteville, R. New urbanism catches on in Canada. New Urban News. 2(2), pp. 1,4-7.

[19] New Urban News. New Urban Projects on a Neighborhood Scale in the United States. New Urban News: Ithaca NY, 2002

[20] Bois-Franc a Saint-Laurent. A new city style. www.boisfranc.com Accessed November 25, 2006.

[21] Duany Plater-Zyberk and Company. Cornell Ontario. (project tear sheet) http://www.dpz.com/projects.aspx Accessed December 9, 2006.

[22] Carlson, K. Back to the future urbanism. Canadian Geographic. www.canadiangeographic.ca/Magazine/mj06/indepth/communities.asp 2006.

[23] Town of Markham. Official Plan for the town of Markham Planning Area Amendment no. 5 (Municipal Housing Statement Study/Urban Area Expansion Study. 1995.

[24] Cinder blocks enforce Quebec subdivision parking rule. CBC.CA News. www.cbc.ca/stories/print/2004/07/03noparking040703 